\title{
Association between serum zinc and copper levels and antioxidant defense in subjects infected with human T-lymphotropic virus type I
}

This article was published in the following Dove Press journal: Journal of Blood Medicine

\section{Samaneh Abolbashari, $1, *$ Susan Darroudi, ${ }^{1, *}$ Maryam Tayefi, ${ }^{2,3}$ Zahra Khashyarmaneh, ${ }^{4}$ Parvin Zamani, ${ }^{5}$ Hamideh Moalemzadeh Haghighi, ${ }^{4}$ Amir Hooshang Mohammadpour, ${ }^{6,7}$ Shima Tavalaei, ${ }^{8}$ Mahsa Ahmadnezhad, ${ }^{9}$ Habibollah Esmaily, ${ }^{10}$ Gordon A Ferns, " Zahra Meshkat, ${ }^{12}$ Majid Ghayour-Mobarhan ${ }^{8}$}

'Student Research Committee, Department of Modern Sciences and Technologies, School of Medicine, Mashhad University of Medical Sciences, Mashhad, Iran; ${ }^{2}$ Cardiovascular Research Center, Mashhad University of Medical Science, Mashhad, Iran; ${ }^{3}$ University International Accreditation, International Office, Clinical Research Unit, Mashhad University of Medical Sciences, Mashhad, Iran; ${ }^{4}$ Department of Medicinal Chemistry, School of Pharmacy, Mashhad University of Medical Sciences, Mashhad, Iran; ${ }^{5}$ Department of Medical Biotechnology, School of Medicine, Mashhad University of Medical Sciences, Mashhad, Iran ${ }^{6}$ Pharmaceutical Research Center, Mashhad University of Medical Sciences, Mashhad, Iran; ${ }^{7}$ Clinical Pharmacy Department, School of Pharmacy, Mashhad University of Medical Sciences, Mashhad, Iran; ${ }^{8}$ Metabolic Syndrome Research Center, Mashhad University of Medical Sciences, Mashhad, Iran; ' Nutrition Research Center, Department of Community Nutrition,

Tabriz University of Medical Sciences, Tabriz, Iran ${ }^{10}$ Department of Biostatistics, School of Health, Mashhad University of Medical Sciences, Mashhad, Iran; "'Brighton and Sussex Medical School, Division of Medical Education, Falmer, Brighton, Sussex, UK; ${ }^{12}$ Antimicrobial Resistance Research Center, Mashhad University of Medical Sciences, Mashhad, Iran

*These authors contributed equally to this work

Correspondence: Zahra Meshkat

Antimicrobial Resistance Research Center, Mashhad University of Medical Sciences, Mashhad, Iran Tel +985I380I2453

Email meshkatz@mums.ac.ir

Majid Ghayour-Mobarhan

Metabolic Syndrome Research Center, School of Medicine, Mashhad University of Medical Sciences, 99199-91766 Mashhad, Iran

$\mathrm{Tel}+985138002288$

$\mathrm{Fax}+985138002287$

Email ghayourm@mums.ac.ir
Introduction: Copper $(\mathrm{Cu})$ and zinc $(\mathrm{Zn})$ are important trace elements that are also structural ions of superoxide dismutase (SOD), which reduce oxidative stress. Zinc deficiency and excess copper have been reported to be associated with inflammation. The human T-lymphotropic virus type 1 (HTLV-1) is a retrovirus, which is believed to cause systemic inflammation. The aim of this study is to measure levels of $\mathrm{Zn}, \mathrm{Cu}, \mathrm{SOD}$, and prooxidant-antioxidant balance (PAB) in HTLV-1-positive patients and investigate the association between serum $\mathrm{Zn}$ and $\mathrm{Cu}$ concentrations and levels of oxidative stress in them.

Methods: The serum samples of 1,116 subjects who had participated in the "Mashhad Stroke and Heart Atherosclerotic Disorder" study, including 279 HTLV-1-positive and 837 HTLV1-negative patients, were used. Levels of $\mathrm{Zn}, \mathrm{Cu}, \mathrm{SOD}$, and PAB were measured.

Results: Zinc and SOD levels were lower in the HTLV-1-positive group; however, the difference was statistically significant only for the level of $\operatorname{SOD}(P=0.003)$. On the other hand, levels of copper and PAB were significantly higher in HTLV- 1 positive subjects; $P=0.004$ and $P=0.002$, respectively. Conclusion: In HTLV-infected patients, serum $\mathrm{Zn}$ concentration is lower and $\mathrm{Cu}$ concentration is higher than healthy controls. This altered situation might be either primary or secondary to HTLV-1 infection, which should be investigated in larger studies. We showed that SOD is significantly lower in HTLV-1-infected subjects. As in some other viruses that evolve different mechanisms to potentiate virus replication by changing the physiologic condition of host cells, HTLV-1 too probably decreases the activity of copper-zinc SOD1 by suppressing its gene.

Keywords: HTLV-1, trace elements, superoxide dismutase, prooxidant-oxidant balance

\section{Introduction}

The human T-lymphotropic virus type 1 (HTLV-1) is a retrovirus that belongs to the Retroviridae family and is classified in the Deltaretrovirus genus. ${ }^{1}$ This virus was discovered in 1979 in association with T-cell leukemia. ${ }^{2,3}$ Some regions in the world are highly endemic for this virus; including southwestern Japan, sub-Saharan Africa, South America, and the Caribbean area. ${ }^{4}$ Northeastern Iran has also been introduced as an endemic region in which the prevalence of HTLV-1 infection was reported to be $2-3 \% .^{5}$

Adult T-cell leukemia and an inflammatory condition called HTLV-1-associated myelopathy/tropical spastic paraparesis (HAM/TSP) are the two main diseases caused by this virus. ${ }^{6}$ The modes of transmission of the virus are mainly through sexual contact with an infected person; mother-to-child, particularly through breastfeeding; and blood transfusion. ${ }^{1}$

HTLV-1 causes systemic inflammation. The pathogenesis is either autoimmune antigen mimicry, in which the immune system attacks host cells because of antigen 
cross reaction with HTLV-1 antigens, or innocent bystander in which the cytokines secreted by HTLV-1-specific cytotoxic cells damage the surrounding tissues. ${ }^{7}$

In patients diagnosed with HAM/TSP, signs of active and acute inflammation were shown to be associated with more severe form of HAM/TSP. ${ }^{8}$

Reactive oxygen species (ROS) are metabolites of oxygen with strong oxidizing capabilities. They are produced by cells that are involved in the host-defense response and can cause endothelial dysfunction by oxidation of cellular signaling proteins. ${ }^{9}$ While low concentrations of ROS serve as signaling molecules, chronic or prolonged ROS production is associated with the progression of inflammation. ${ }^{9}$ In normal conditions, a balance is maintained between the production and elimination of the ROS. The role of oxidative stress (OS), which is the consequence of an imbalance between ROS and antioxidant factors, ${ }^{10}$ has been approved in various inflammatory diseases and chronic infections. ${ }^{11}$

Superoxide dismutase (SOD) is an antioxidant factor that removes the superoxide species. ${ }^{12}$ Three forms of SOD are known so far, which include the cytosolic $\mathrm{Cu} / \mathrm{ZnSOD}$ (SOD1), the mitochondrial MnSOD (SOD2), and the extracellular superoxide dismutase (SOD3). ${ }^{13}$ The catalytic reaction of $\mathrm{Cu} / \mathrm{ZnSOD}$ is performed by the cyclic reduction and oxidation of the copper ion $\left(\mathrm{Cu}^{2+}\right){ }^{12}$

The prooxidant-antioxidant balance (PAB), which can be measured in a single assay, ${ }^{10}$ has been reported as a potential cardiovascular risk factor. ${ }^{14}$

Copper $(\mathrm{Cu})$ and zinc $(\mathrm{Zn})$ are important trace elements that act as ion cofactors in proteins, hormones, and receptors and also as cofactors in numerous enzymatic reactions. ${ }^{15}$ They are structural ions of $\mathrm{SOD}^{16}$ and reduce OS by induction of metallothionein synthesis. ${ }^{17,18}$ Because of their pivotal role in the redox mechanisms, their imbalanced status may lead to an increased susceptibility to oxidative damage. ${ }^{19-21}$

While acute $\mathrm{Zn}$ deficiency causes a decrease in innate and adaptive immunity, chronic deficiency increases inflammation. ${ }^{22}$ On the other hand, excess $\mathrm{Cu}$ is probably associated with an inflammatory response, although it is not clear whether copper has prooxidant or antioxidant effects. This is because ceruloplasmin, as the main copper-containing protein, has been shown to act both as an antioxidant and prooxidant in different conditions. ${ }^{23}$

Tax, which is an important regulatory protein encoded by the HTLV-1 genome, is essential for the replication of the virus. On the other hand, numerous studies indicate that continuous TAX production is associated with apoptosis, and OS is identified as the mediator of TAX-induced apoptosis.
The oxidative damage induced by Tax is mediated by the transcriptional activation of nuclear factor kappa $\mathrm{B}(\mathrm{NF}-\kappa \mathrm{B})$ by the Tax. NF- $\kappa \mathrm{B}$ is itself a prooxidant nuclear transcription factor. ${ }^{24}$

One of the first proofs of the involvement of prooxidants in the functionality of Tax was the use of antioxidants. A radical scavenger called pyrrolidine dithiocarbamate was shown to strongly suppress the Tax-induced activation of the DNA-binding activity of NF- $\kappa \mathrm{B}$ in Jurkat cells. ${ }^{25}$

On the other hand, it has been shown that total antioxidant capacity (TAC) is depleted during HTLV-1 infection. ${ }^{11}$

Considering the fact that both HTLV-1 infection and abnormal serum levels of $\mathrm{Zn}$ and $\mathrm{Cu}$ could lead to systemic inflammation, and taking into account that OS plays an important role in both of their mechanisms, in the current study, we measured levels of $\mathrm{Zn}$ and $\mathrm{Cu}$ in HTLV-1-positive patients in a control group. We also assessed the association between serum $\mathrm{Zn}$ and $\mathrm{Cu}$ concentrations and levels of $\mathrm{OS}$ in HTLV-1-infected subjects by measuring SOD-1 and PAB.

\section{Materials and methods Study population}

In the current study, the serum samples of 1,116 subjects who had participated in the "Mashhad Stroke and Heart Atherosclerotic Disorder (MASHAD)" study were used, and the participants were selected through cluster-randomized allocation methodology. ${ }^{26}$ The study's protocol was approved by Mashhad University of Medical Sciences Ethics committee and all participants provided informed written consents. This study was conducted in accordance with the Declaration of Helsinki.

The inclusion and exclusion criteria of MASHAD study and the public features of the study's population including marital status, occupation status, education level, drug use, and biochemical and anthropometry measurements were explained previously. ${ }^{26}$ For the current study, 279 HTLV1-positive patients as well as 837 HTLV-1-negative patients who matched the first group by age and sex were selected.

\section{Sample collection}

Twenty milliliters of blood was taken by venipuncture of an antecubital vein in vacuum tubes. Specimens were centrifuged at room temperature within 30-45 minutes of collection to separate the serum, which were then divided into aliquots and kept frozen at $-20^{\circ} \mathrm{C}$ for future analysis.

\section{HTLV-I infection assessment}

The serum samples of all participants of MASHAD study were screened for HTLV-1-specific antibodies by ELISA 
(Dia.Pro Diagnostic, Italy). Positive cases were assessed for the HTLV-1 genome using PCR for TAX- and LTR-specific primers to confirm the infection. Patients were confirmed to be infected by HTLV-1 if either of the genes were present. A total of 279 HTLV-1-infected patients were identified who were enrolled in the current study.

\section{Measurement of serum zinc and copper concentrations}

Serum samples were diluted with nitric acid at the ratio of 1:10. Using the flame atomic absorption (Varian AA240FS), the concentrations of $\mathrm{Zn}$ and $\mathrm{Cu}$ were evaluated. Also, using $\mathrm{Zn}$ and $\mathrm{Cu}$ standards (Merc and Co. Pharmaceutical Company), the $\mathrm{Zn}$ and $\mathrm{Cu}$ standard curves were created. The accuracy of the methods for $\mathrm{Zn}$ and $\mathrm{Cu}$ were $93 \% \pm 4.8 \%$ and $95 \% \pm 3.75 \%$, respectively, which were assessed through measuring the confirmed reference material (MercK KGaA 64271 Darmstadt, Germany) comprising known values (1000土2 mg/ L) for $\mathrm{Zn}$ and $\mathrm{Cu}$. The intra-assay and inter-assay coefficient of variation for $\mathrm{Zn}$ and $\mathrm{Cu}$ were also calculated and equal to $1.5 \% \pm 0.2 \%$, $2.6 \% \pm 0.4 \%, 1.3 \% \pm 0.12 \%$, and $2.11 \% \pm 0.32 \%$, respectively.

\section{PAB measurement}

As mentioned before, the PAB test is the only assay capable of checking the balance of oxidants and antioxidants concurrently in a test. PAB values were evaluated in the serum samples through a modified PAB test that has been previously described. ${ }^{10}$ Briefly, for making a standard solution, varying portions $(0 \%-100 \%)$ of $250 \mu \mathrm{M}$ hydrogen peroxide $\left(\mathrm{H}_{2} \mathrm{O}_{2}\right)$ were mixed with $3 \mathrm{mM}$ uric acid (in $10 \mathrm{mM} \mathrm{NaOH}$ ). Sixty milligrams of TMB powder was dissolved in $10 \mathrm{~mL}$ DMSO. For making TMB cation, $400 \mu \mathrm{L}$ of the TMB/DMSO was mixed with $20 \mathrm{~mL}$ acetate buffer (0.05 M buffer, $\mathrm{pH} 4.5)$. Subsequently, $70 \mu \mathrm{L}$ of fresh chloramine T solution $(100 \mathrm{mM})$ was added to this $20 \mathrm{~mL}$ of acetate buffer. Next, we mixed the solution and incubated it at the room temperature for 2 hours. Then, $25 \mathrm{U}$ of peroxidase enzyme solution was mixed with TMB cation solution, distributed in $1 \mathrm{~mL}$ and stored at $-20^{\circ} \mathrm{C}$. Also, for making TMB solution, $200 \mu \mathrm{L}$ of TMB/DMSO was mixed with $10 \mathrm{~mL}$ of acetate buffer (0.05 $\mathrm{M}$ buffer, $\mathrm{pH} 5.8)$ and the working solution was made by adding $1 \mathrm{~mL}$ TMB cation to $10 \mathrm{~mL}$ of TMB solution. Afterwards, the solution was incubated for 2 minutes at room temperature and immediately used. After that, $10 \mu \mathrm{L}$ of each of the samples as well as the standard or blank (distilled water) were mixed with $200 \mu \mathrm{L}$ of working solution in each well of a 96-well plate. The plate was incubated for 12 minutes at $37^{\circ} \mathrm{C}$ in a dark environment. After incubation, $100 \mu \mathrm{L}$ of $2 \mathrm{~N}$ hydrochloric acid (HCL) was appended in each well and the OD was evaluated with an ELISA reader at $450 \mathrm{~nm}$, with a reference wavelength of 620 or $570 \mathrm{~nm}$. According to the values comparative to the standard samples, a standard curve was drawn. The values of PAB in the arbitrary HK unit are expressed as the percentage of hydrogen peroxide in the standard solution. Then, based on the amounts from the above standard curve, the values of unknown samples were calculated. ${ }^{14}$

\section{SOD measurement}

Primarily, for making Tris-cacodylic acid buffer (0.05 M, $\mathrm{pH}$ 8.2) comprising $0.001 \mathrm{M}$ diethylenetriamine pent acetic acid (DTPA), Tris (0.05 M, containing 0.001 M DTPA) was appended to cacodylic acid $(0.05 \mathrm{M}$, containing $0.001 \mathrm{M}$ DTPA) until $\mathrm{pH}=8.2$ was obtained. Prior to use, the buffer was air-balanced for 1 hour. For pyrogallol preparation, a source of $0.02 \mathrm{M}(100 \times)$ pyrogallol solution was constructed in water. To remove soluble oxygen, it was flushed with nitrogen for 1 hour, then aliquoted $(100 \mu \mathrm{L}$ per aliquot), and finally stored frozen until used. After that, $20 \mu \mathrm{L}$ of each serum and control was added in duplicate wells. Also, using the equilibrated assay buffer, pyrogallol stock solution (0.02 $\mathrm{M}$ ) was diluted 1:100, and $180 \mu \mathrm{L}$ per well of the solution was added through a multichannel pipettor. The reactions were read on a plate reader at $405 \mathrm{~nm}$ at intervals of 5 minutes for 1 hour. The SOD level, which inhibited pyrogallol oxidation by $50 \%$ (relative to control), was defined as an SOD activity unit in the described conditions. ${ }^{27}$

\section{Statistical analyses}

In the current study, SPSS Version 18 (SPSS Inc. Chicago, IL, USA) was used for all statistical analyses. The normality of the data was evaluated through the Kolmogorov-Smirnov test. Descriptive statistics containing mean, frequency, and SD were evaluated for all variables. Normally distributed variables were expressed by mean $\pm \mathrm{SD}$, while parameters that were not normally distributed were expressed by median \pm IQR. Chi-square or Fisher's exact assays were applied for the assessment of categorical parameters. To investigate the correlation between PAB, SOD, and HTLV1 , partial correlation and linear regression were utilized. A two-sided $P$-value of $<0.05$ was considered statistically significant. Figures were drawn using GraphPad Prism 6.

\section{Results \\ Levels of zinc, copper, SOD, and PAB}

Table 1 shows the mean serum concentration of $\mathrm{Zn}$ and $\mathrm{Cu}$ and also the levels of SOD and PAB in both groups. $\mathrm{Zn}$ and 
SOD levels were lower in the HTLV-1-positive group; however, the difference was statistically significant only for the level of SOD $(P=0.003)$. On the other hand, levels of $\mathrm{Cu}$ and PAB were significantly higher in HTLV-1-positive subjects ( $P=0.004$ and $P=0.002$, respectively).

The copper-to-zinc ratio was also significantly higher in the HTLV-1-positive group $(P<0.001)$.

Table I Mean levels of zinc, copper, SOD, and PAB in HTLV-Ipositive and -negative patients

\begin{tabular}{|l|l|l|l|}
\hline Variable & $\begin{array}{l}\text { HTLV-I } \\
\text { negative }\end{array}$ & $\begin{array}{l}\text { HTLV-I } \\
\text { positive }\end{array}$ & P-value \\
\hline $\begin{array}{l}\text { Zinc, } \mu \mathrm{g} / \mathrm{dL}(\mathrm{normal} \\
\text { range: } 65-\mathrm{I} 10 \mu \mathrm{g} / \mathrm{dL})\end{array}$ & $84.18 \pm 18.26$ & $83.16 \pm 17.56$ & $0.4 \mathrm{I}$ \\
\hline $\begin{array}{l}\text { Copper, } \mu \mathrm{g} / \mathrm{dL}(\mathrm{normal} \\
\text { range: } 80-150 \mu \mathrm{g} / \mathrm{dL})\end{array}$ & $103.75 \pm 38.56$ & $\mathrm{III} .27 \pm 35.77$ & 0.004 \\
\hline Copper/zinc ratio & $\mathrm{I} .28 \pm 0.82$ & $1.5 \pm 0.64$ & $<0.00 \mathrm{I}$ \\
\hline $\mathrm{PAB}, \mathrm{HK}$ & $68.15 \pm 50.67$ & $80.32 \pm 46.59$ & 0.002 \\
\hline SOD, IU & $19.94 \pm 14.52$ & $16.79 \pm 12.59$ & 0.003 \\
\hline
\end{tabular}

Abbreviations: HTLV-I, human T-lymphotropic virus type I; PAB, prooxidantantioxidant balance; SOD, superoxide dismutase.

\section{Correlation between zinc and SOD, SOD and PAB, and copper and SOD}

We found a positive relationship between levels of $\mathrm{Zn}$ and SOD in HTLV-1-positive patients; however, the relationship was not statistically significant $(r=0.016, P=0.82)$ (Figure 1 ). Also, it was shown that there is a significant positive correlation between $\mathrm{Cu}$ and $\mathrm{SOD}(r=0.097, P<0.001)$ (Figure 2), as well as a significant reverse correlation between the level of SOD and PAB ( $r=-0.033, P=0.016$ ) (Figure 3 ).

\section{Discussion}

The results of this study show that in HTLV-infected patients, serum $\mathrm{Zn}$ concentration is lower and $\mathrm{Cu}$ concentration is higher than healthy controls. To the best of our knowledge, no other study has yet assessed the levels of these trace elements in HTLV-1-infected patients.

Although serum levels of both $\mathrm{Zn}$ and $\mathrm{Cu}$ are in normal ranges for the Iranian population in both cases and control groups, ${ }^{28-30}$ further studies are required to reveal whether the different serum $\mathrm{Zn}$ and $\mathrm{Cu}$ levels in HTLV-1 patients has

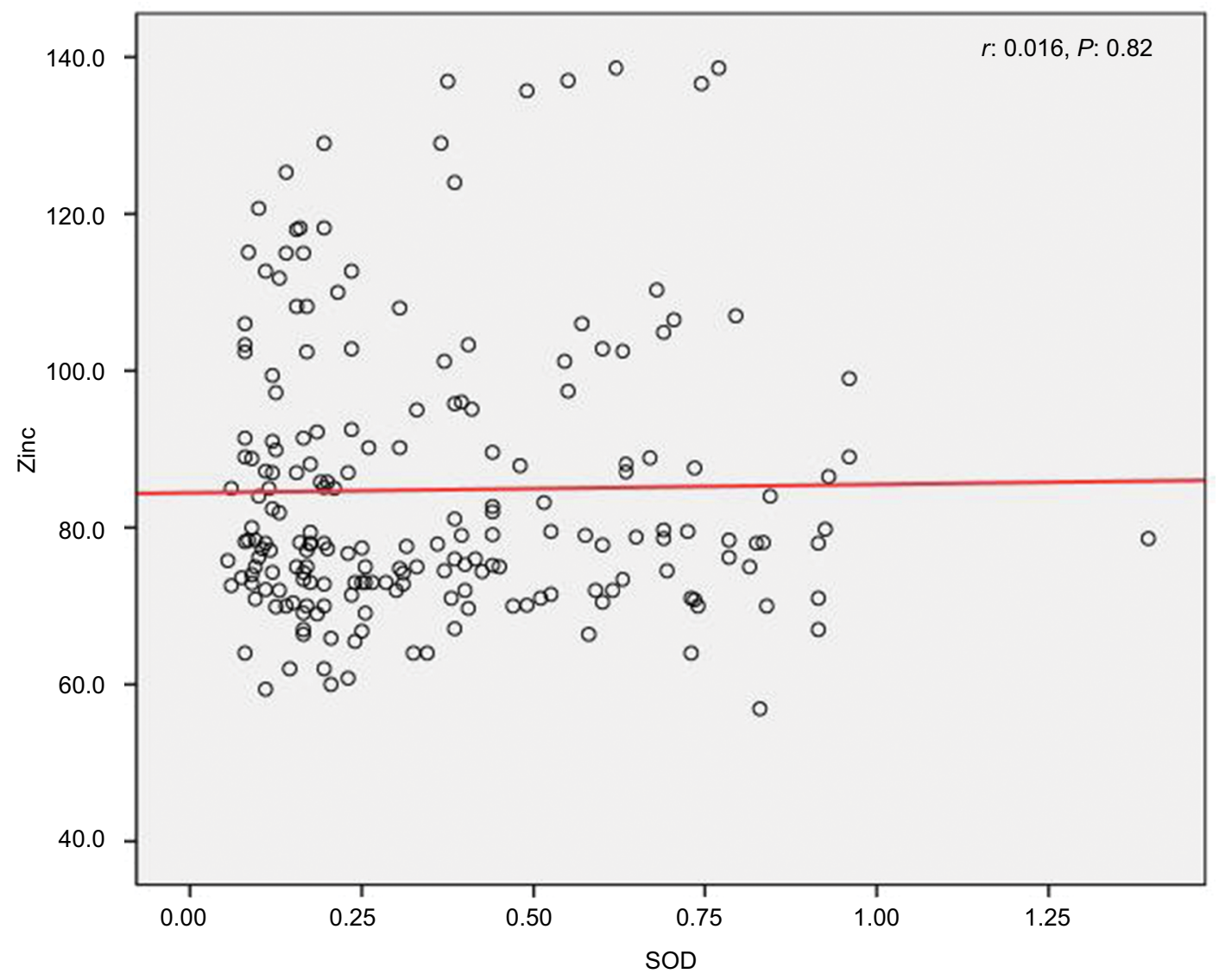

Figure I Correlation between levels of zinc and SOD in human T-lymphotropic virus type I-positive patients. Abbreviation: SOD, superoxide dismutase. 


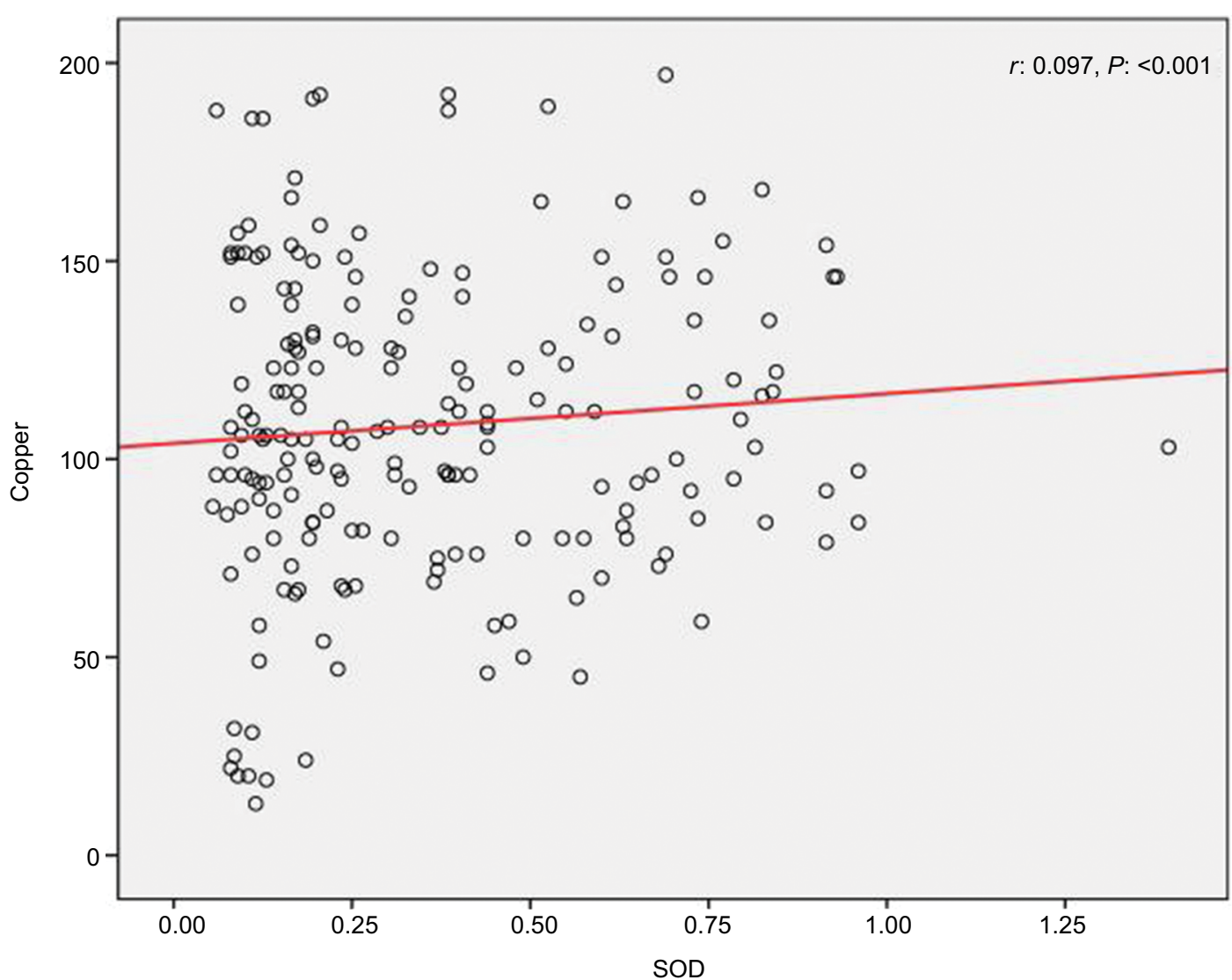

Figure 2 Correlation between copper and SOD.

Abbreviation: SOD, superoxide dismutase.

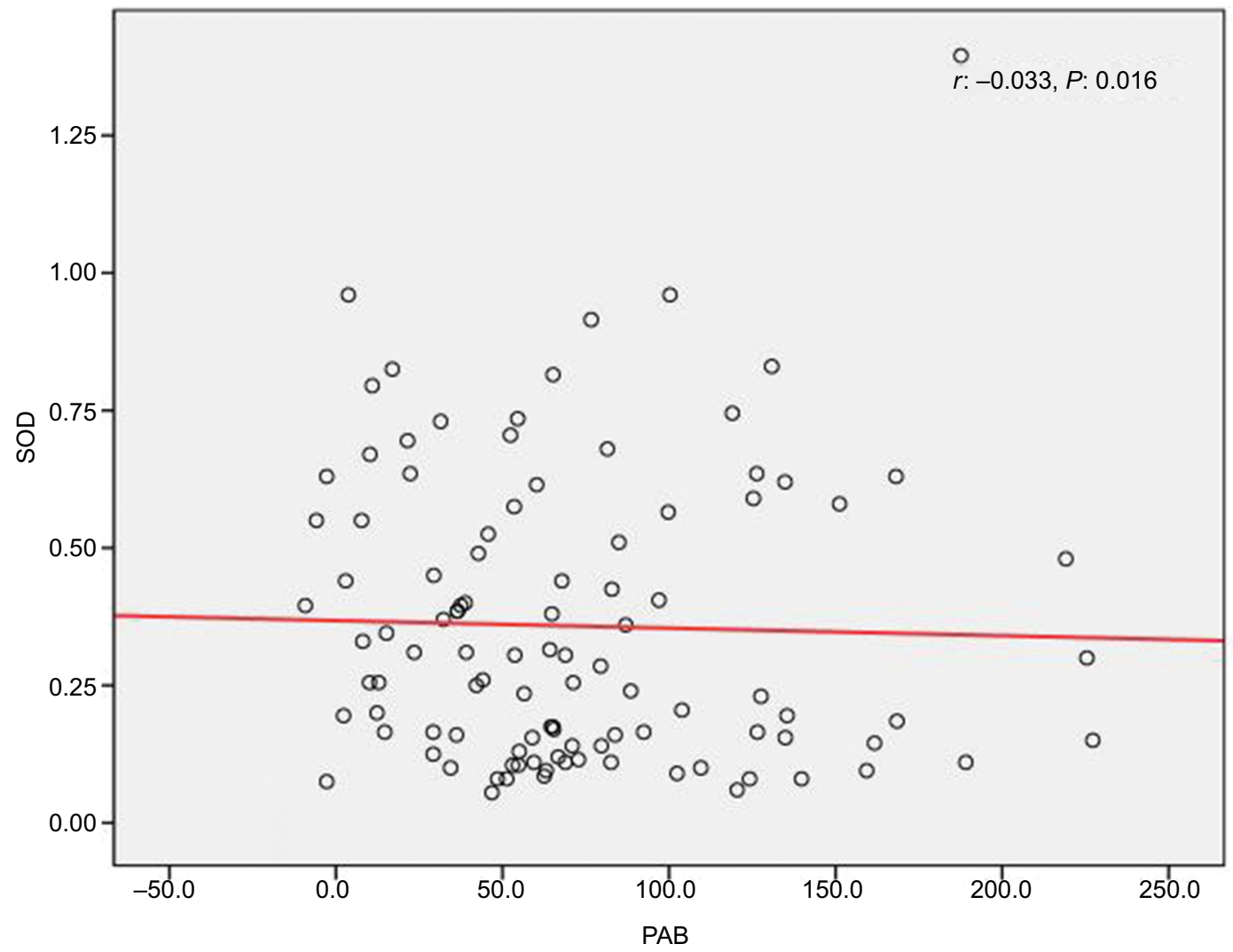

Figure 3 Correlation between SOD and PAB.

Abbreviations: $\mathrm{PAB}$, prooxidant-antioxidant balance; SOD, superoxide dismutase. 
led to the increased susceptibility to infection in them or the infection itself has led to different $\mathrm{Zn}$ and $\mathrm{Cu}$ levels.

Both $\mathrm{Zn}$ and $\mathrm{Cu}$ are claimed to protect organisms against infectious diseases and to regulate innate immune response. ${ }^{31}$ However, the etiology of altered plasma $\mathrm{Zn}$ and $\mathrm{Cu}$ concentrations associated with proinflammatory conditions is yet to be determined. ${ }^{32}$

The increased serum copper-to-zinc ratio is shown to be associated with an altered homeostatic status after a destabilizing event and is also associated with an inflammatory response..$^{32} \mathrm{Also}$, the combination of low serum $\mathrm{Zn}$ and high serum $\mathrm{Cu}$ is contributed to an increased risk of cardiovascular diseases. ${ }^{33}$ Our results show a significant increase in the copper-to-zinc ratio in the HTLV-1-infected subjects in comparison to controls. This finding could be an explanation for the systemic inflammation seen in HTLV-1 infection, both in asymptomatic carriers and symptomatic patients.

We showed that SOD1 is significantly lower in HTLV1 -infected subjects. It is well known that viruses evolve different mechanisms to potentiate virus replication, by changing the physiologic condition of host cells. For example, it has been shown that influenza virus A increases superoxide anion level in human alveolar cells, mainly by suppressing the copper-zinc SOD1 gene. ${ }^{34}$ In another example, the expression of the regulatory Tat protein from the human immunodeficiency virus type 1 (HIV-1) was shown to suppress the expression of cellular Mn-containing superoxide dismutase (Mn-SOD). ${ }^{35}$ This might be the case for what is happening in HTLV-1 infection as well.

Also, the important regulatory protein Tax from HTLV-1 is shown to resemble other viral and cellular oncogenes like adenovirus E1A, simian virus 40 large tumor antigen, and the human papilloma virus E7 proteins, which aside from their transforming properties have the ability to induce apoptosis. ${ }^{24}$ On the other hand, it has been demonstrated that the induction of OS was a prompt effect of TAX function and this OS is a mediator of TAX-induced apoptosis. ${ }^{24}$ This effect is commonly observed in other viral proteins that cause apoptosis, such as HIV-1 Tat protein..$^{35}$ As HTLV-1 and HIV-1 share similar genomic organization and tropism for immune cells, in particular $\mathrm{CD}^{+}$and $\mathrm{CD}^{+} \mathrm{T}$ cells, their role in OS could be similar.

In a study that evaluated the serum level of trace elements $\mathrm{Zn}, \mathrm{Cu}, \mathrm{Mg}$, and $\mathrm{Se}$, and assessed the level of OS in children with type 1 diabetes, levels of all four elements and also the OS parameters were significantly lower in diabetic patients than in the controls. ${ }^{36}$

We found a positive correlation between SOD and $\mathrm{Cu}$ and a negative correlation between SOD and PAB. We, therefore, assume that there might be a negative correlation between $\mathrm{Cu}$ and PAB. This assumption is in favor of what has been reported by Alamdari et al, which is a negative correlation between PAB and ceruloplasmin..$^{14}$ They have discussed that ceruloplasmin behaves as an antioxidant.

Regarding the association between HTLV-1 infection and antioxidant defense, in 2014, Shomali et al have investigated the TAC in the serum of HTLV-1-infected patients. They have reported that TAC is depleted during HTLV- 1 infection. This reduction was seen in both asymptomatic carriers of HTLV-1 and those who had symptoms of HAM/TSP. ${ }^{11}$ This finding is relevant with the lower SOD levels in HTLV-1-infected subjects, which is shown in the present study.

Revealing the exact mechanisms by which ROS are involved in the regulation of T-cell functions is important to achieve a good insight of the immune response, and to develop new treatments for the control of immune-mediated diseases. ${ }^{37}$

\section{Limitations}

In this study, assessment of the relation between SOD and zinc and copper levels was not separately done in asymptomatic HTLV-1 carriers and those with symptoms. As symptomatic patients usually have higher viral loads, it is necessary to distinguish the two groups when studying the effects of the virus on different biologic mechanisms.

\section{Conclusion}

The decreased serum $\mathrm{Zn}$ and increased serum $\mathrm{Cu}$ in HTLV1 -infected subjects along with an increased $\mathrm{Cu} / \mathrm{Zn}$ ratio confirms the fact that infection with this virus is associated with general inflammation. On the other hand, because the antioxidant capacity is reduced in these patients, supplying them with antioxidants could help postpone the incidence of symptoms.

\section{Acknowledgment}

This study was part of two Molecular Medicine $\mathrm{PhD}$ theses (codes: 940247 and 941175) sponsored by Mashhad University of Medical Sciences, Mashhad, Iran.

\section{Disclosure}

The authors report no conflicts of interest in this work.

\section{References}

1. Verdonck K, González E, van Dooren S, Vandamme AM, Vanham G, Gotuzzo E. Human T-lymphotropic virus 1: recent knowledge about an ancient infection. Lancet Infect Dis. 2007;7(4):266-281.

2. Popovic M, Reitz MS, Sarngadharan MG, et al. The virus of Japanese adult T-cell leukaemia is a member of the human T-cell leukaemia virus group. Nature. 1982;300(5887):63-66. 
3. Poiesz BJ, Ruscetti FW, Mier JW, Woods AM, Gallo RC. T-cell lines established from human T-lymphocytic neoplasias by direct response to T-cell growth factor. Proc Natl Acad Sci USA. 1980;77(11):6815-6819.

4. Gessain A, Cassar O. Epidemiological aspects and world distribution of HTLV-1 infection. Front Microbiol. 2012;3:388.

5. Rafatpanah H, Hedayati-Moghaddam MR, Fathimoghadam F, et al. High prevalence of HTLV-I infection in Mashhad, Northeast Iran: a population-based seroepidemiology survey. J Clin Virol. 2011;52(3):172-176.

6. Souza A, Tanajura D, Toledo-Cornell C, Santos S, Carvalho EM. Immunopathogenesis and neurological manifestations associated to HTLV-1 infection. Rev Soc Bras Med Trop. 2012;45(5):545-552.

7. Bangham CR, Osame M. Cellular immune response to HTLV-1. Oncogene. 2005;24(39):6035-6046.

8. Puccioni-Sohler M, Gasparetto E, Cabral-Castro MJ, et al. HAM/ TSP: association between white matter lesions on magnetic resonance imaging, clinical and cerebrospinal fluid findings. Arq Neuropsiquiatr. 2012;70(4):246-251.

9. Mittal M, Siddiqui MR, Tran K, Reddy SP, Malik AB. Reactive oxygen species in inflammation and tissue injury. Antioxid Redox Signal. 2014;20(7):1126-1167.

10. Alamdari DH, Paletas K, Pegiou T, Sarigianni M, Befani C, Koliakos G. A novel assay for the evaluation of the prooxidant-antioxidant balance, before and after antioxidant vitamin administration in type II diabetes patients. Clin Biochem. 2007;40(3-4):248-254.

11. Shomali S, Avval FZ, Boostani R, Jarahi L, Youssefi M. Serum total antioxidant capacity status of HTLV-1 infected patients. Acta Virol. 2015;59(2):199-203.

12. Bordo D, Djinović K, Bolognesi M. Conserved patterns in the $\mathrm{Cu}, \mathrm{Zn}$ superoxide dismutase family. J Mol Biol. 1994;238(3):366-386.

13. Fridovich I. Superoxide anion radical (O2-.), superoxide dismutases, and related matters. J Bio Chem. 1997;272(30):18515-18517.

14. Alamdari DH, Ghayour-Mobarhan M, Tavallaie S, et al. Prooxidantantioxidant balance as a new risk factor in patients with angiographically defined coronary artery disease. Clin Biochem. 2008;41(6):375-380.

15. Fleet JC. Zinc, copper and manganese. In: Stipanuk M, editor. Biochemical and Physiological Aspects of Human Nutrition. Philadelphia, PA: Saunders; 2000.

16. Fukuoka M, Tokuda E, Nakagome K, Wu Z, Nagano I, Furukawa Y. An essential role of $\mathrm{N}$-terminal domain of copper chaperone in the enzymatic activation of $\mathrm{Cu} / \mathrm{Zn}$-superoxide dismutase. J Inorg Biochem. 2017;175:208-216.

17. Rutherford JC, Bird AJ. Metal-responsive transcription factors that regulate iron, zinc, and copper homeostasis in eukaryotic cells. Eukaryot Cell. 2004;3(1):1-13.

18. Saydam N, Adams TK, Steiner F, Schaffner W, Freedman JH. Regulation of metallothionein transcription by the metal-responsive transcription factor MTF-1: identification of signal transduction cascades that control metal-inducible transcription. J Biol Chem. 2002;277(23):20438-20445.

19. Soinio M, Marniemi J, Laakso M, Pyörälä K, Lehto S, Rönnemaa T. Serum zinc level and coronary heart disease events in patients with type 2 diabetes. Diabetes Care. 2007;30(3):523-528.

20. Ceriello A. Oxidative stress and glycemic regulation. Metabolism. 2000;49(2):27-29.
21. Klotz LO, Kröncke KD, Buchczyk DP, Sies H. Role of copper, zinc, selenium and tellurium in the cellular defense against oxidative and nitrosative stress. J Nutr. 2003;133(5):1448S-1451S.

22. Bonaventura $P$, Benedetti G, Albarède F, Miossec P. Zinc and its role in immunity and inflammation. Autoimmun Rev. 2015;14(4):277-285.

23. Bo S, Durazzo M, Gambino R, et al. Associations of dietary and serum copper with inflammation, oxidative stress, and metabolic variables in adults. $J$ Nutr. 2008;138(2):305-310.

24. Chlichlia K, Los M, Schulze-Osthoff K, Gazzolo L, Schirrmacher V, Khazaie K. Redox events in HTLV-1 Tax-induced apoptotic T-cell death. Antioxid Redox Signal. 2002;4(3):471-477.

25. Schreck R, Grassmann R, Fleckenstein B, Baeuerle PA. Antioxidants selectively suppress activation of NF-kappa B by human T-cell leukemia virus type I Tax protein. J Virol. 1992;66(11):6288-6293.

26. Ghayour-Mobarhan M, Moohebati M, Esmaily H, et al. Mashhad stroke and heart atherosclerotic disorder (MASHAD) study: design, baseline characteristics and 10-year cardiovascular risk estimation. Int J Public Health. 2015;60(5):561-572.

27. Ahmed H, Schott EJ, Gauthier JD, Vasta GR. Superoxide dismutases from the oyster parasite Perkinsus marinus: purification, biochemical characterization, and development of a plate microassay for activity. Anal Biochem. 2003;318(1):132-141.

28. Mashhadi MA, Bakhshipour A, Zakeri Z, Ansari-Moghadam A. Reference range for zinc level in young healthy population in southeast of Iran. Health Scope. 2017;6(1):e18181.

29. Dabbaghmanesh MH, Salehi NM, Siadatan J, Omrani GR. Copper concentration in a healthy urban adult population of southern Iran. Biol Trace Elem Res. 2011;144(1-3):217-224.

30. Parizadeh SMR, Kazemi-Bajestani SMR, Moghaddam AS, et al. Serum zinc and copper concentrations and socioeconomic status in a large Persian cohort. Asian Biomedicine. 2011;5(3):329.

31. Stafford SL, Bokil NJ, Achard ME, et al. Metal ions in macrophage antimicrobial pathways: emerging roles for zinc and copper. Biosci Rep. 2013;33(4):541-554.

32. Malavolta M, Piacenza F, Basso A, Giacconi R, Costarelli L, Mocchegiani E. Serum copper to zinc ratio: relationship with aging and health status. Mech Ageing Dev. 2015;151:93-100.

33. Leone N, Courbon D, Ducimetiere P, Zureik M. Zinc, copper, and magnesium and risks for all-cause, cancer, and cardiovascular mortality. Epidemiology. 2006;17(3):308-314.

34. Pyo CW, Shin N, Jung KI, Choi JH, Choi SY. Alteration of copper-zinc superoxide dismutase 1 expression by influenza A virus is correlated with virus replication. Biochem Biophys Res Commun. 2014;450(1): 711-716.

35. Flores SC, Marecki JC, Harper KP, Bose SK, Nelson SK, McCord JM. Tat protein of human immunodeficiency virus type 1 represses expression of manganese superoxide dismutase in HeLa cells. Proc Natl Acad Sci USA. 1993;90(16):7632-7636.

36. Alghobashy AA, Alkholy UM, Talat MA, et al. Trace elements and oxidative stress in children with type 1 diabetes mellitus. Diabetes Metab Syndr Obes. 2018;11:85-92.

37. Belikov AV, Schraven B, Simeoni L. T cells and reactive oxygen species. J Biomed Sci. 2015;22:85.
Journal of Blood Medicine

\section{Publish your work in this journal}

The Journal of Blood Medicine is an international, peer-reviewed, open access, online journal publishing laboratory, experimental and clinical aspects of all aspect pertaining to blood based medicine including but not limited to: Transfusion Medicine; Blood collection, Donor issues, Transmittable diseases, and Blood banking logistics; Immunohematology; Artificial and alternative blood based therapeutics; Hematology; Biotechnology/nanotechnology of blood related medicine; Legal aspects of blood medicine; Historical perspectives. The manuscript management system is completely online and includes a very quick and fair peer-review system. Visit http://www.dovepress.com/ testimonials.php to read real quotes from published authors. 